DOI: $10.14451 / 1.182 .82$

\title{
ПРОБЛЕМЫ ПЕНСИОННОЙ РЕФОРМЫ В РОССИЙСКОЙ ФЕДЕРАЦИИ
}

\author{
(c) 2020 Иванова Людмила Кирилловна
}

старший преподаватель кафедры финансов, денежного обращения и экономической безопасности Уфимский государственный авиационный технический университет, Россия, Уфа

E-mail:smr ufa@mail.ru

ORCID: 0000-0002-4345-1325

В Российской Федерации проводится пенсионная реформа. Изменен порядок назначения и выплаты пенсий, порядок индексации ее размеров, увеличен возраст выхода на пенсию. В статье приведены примеры расчета пенсии для работников с минимальным размером оплаты труда и работников с высокой зарплатой. Рассмотрены существующие проблемы, связанные с увеличением пенсионного возраста, сложности трудоустройства лиц предпенсионного возраста, отсутствия индексации пенсий работающим пенсионерам и другие.

Ключевые слова: пенсионная реформа, пенсионное страхование, пенсионное обеспечение, увеличение пенсионного возраста.

Пенсионная реформа - это целенаправленная политика государства, связанная с изменением законодательства, направленная на изменение условий пенсионного обеспечения.

Наш народ пережил не одну пенсионную реформу. В СССР пенсионное обеспечение вводили постепенно для определенных категорий граждан. В 1932 году законодательно установили возраст выхода на пенсию по старости 55 лет для женщин и 60 лет для мужчин, а с 1937 года пенсии стали выплачивать всем городским рабочим и служащим. Окончательно система пенсионного обеспечения в СССР сформирована в 1956 году, когда был принят Закон «О государственных пенсиях» от 14 июля 1956 года. Закон предусматривал пенсии по старости, по инвалидности и по случаю потери кормильца, устанавливал единые основания назначения пенсий, единый возраст и требования к трудовому стажу, единый порядок исчисления размера пенсий. Мужчины выходили на пенсию по старости в 60 лет при условии, что трудовой стаж не менее 25 лет, женщины - в 55 лет при условии, что трудовой стаж не менее 20 лет. Для работников с тяжелыми условиями труда возраст выхода на пенсию был на пять лет меньше. Для рабочих и служащих на подземных работах, с вредными условиями труда и в горячих цехах пенсионный возраст был 50 лет - для мужчин (при стаже не менее 20 лет); 45 лет - для женщин (при стаже не менее 15 лет). Для работниц предприятий текстильной промышленности - 50 лет (при стаже не менее 20 лет).
Возраст окончания трудоспособности был установлен на основе заключения врачей, что здоровье женщин в 55, а мужчин в 60 лет, не позволяет работать продуктивно.

Пенсии рассчитывались исходя из средней зарплаты за последний год или последние десять лет работы. Дополнительный стаж незначительно влиял на размер пенсии.

В Российской Федерации были приняты Федеральные законы от 15.12.2001 г. № 166-Ф3 «О государственном пенсионном обеспечении в Российской Федерации» [7] и № 167-ФЗ «Об обязательном пенсионном страховании в Российской Федерации» [8], от 17.12.2001 г. Федеральный закон № 173-Ф3 «О трудовых пенсиях» [6]. Пенсионный возраст, установленный в СССР менять не стали.

Нынешнюю реформу запустили в 2013 году, когда было принято два Федеральных закона от 28.12.2013 г. № 400-Ф3 «О страховых пенсиях» [3] и № 424-Ф3 «О накопительной пенсии» [4], которые вступили в силу с 1 января 2015 года и кардинально изменили порядок расчета пенсии. Утвержденная система подсчета стала более сложной, самостоятельно посчитать, сколько будешь получать пенсии, довольно трудно. В формуле расчета присутствуют сумма индивидуальных пенсионных коэффициентов за все годы трудовой деятельности работника, стоимость одного пенсионного коэффициента (так называемый пенсионный балл) по состоянию на день, с которого назначается пенсия и фиксированная выплата. Размер фиксированной выплаты еже- 
годно меняется, также как и стоимость пенсионного коэффициента. И совершенно невозможно предугадать, что это будут за величины через 25-30 лет работы. При этом размер пенсий у практически всех категорий граждан уменьшился по сравнению с ранее действовавшей системой.

Россия подписала Конвенцию № 102 Международной организации труда (MOT) [2], устанавливающую минимальный коэффициент замещения пенсий на уровне $40 \%$ от зарплаты. Также государство имеет конституционные обязательства перед гражданами.

И вот новый виток в пенсионной реформе запускается Федеральным законом от 03.10.2018 г. № 350-Ф3 [5]: изменяется порядок назначения и выплаты пенсий, порядок индексации ее размеров, устанавливается пенсионный возраст для женщин - 60 лет, для мужчин - 65 лет. Новый норматив возраста выхода на пенсию будет повышаться постепенно в течение 5 лет.

Повышается возраст, достижение которого дает право на оформление социальной пенсии по старости. Предусматривается, что право на социальную пенсию теперь имеют постоянно проживающие в РФ граждане РФ, достигшие возраста 70 и 65 лет (соответственно мужчины и женщины). Ранее указанный возраст составлял 65 и 60 лет соответственно.

Несмотря на повышение пенсионного возраста, материальное обеспечение российских пенсионеров не улучшилось. А многие из них вообще не получат пенсию по старости, т.к. для назначения пенсии нужно еще два условия - наличие стажа, в течение которого производилась уплата страховых взносов в пенсионный фонд РФ и количество пенсионных баллов. В 2019 году минимально необходимый стаж составлял 10 лет и минимальный балл 16,2; к 2025 году необходимый стаж 15 лет, минимальный балл 30. Отказы в назначении страховой пенсии по старости в 2017 году получили 125 тысяч человек, в 2018 - более 170 тысяч человек. Это те, кому государство отказало в назначении пенсии по причине недостаточного трудового стажа и суммы выплаченных взносов. По приблизительным подсчетам в нелегальной занятости в настоящее время насчитывается 15 млн. человек, которые вскоре пополнят ряды пенсионеров не обеспеченных пенсиями.

С 2014 года заморожены обязательные взносы на накопительную часть пенсий, с 2016 года отменили индексацию пенсий работающим пенсионерам. Глава ПФР Антон Дроздов заявил тогда, что у его ведомства нет средств на то, чтобы проиндексировать все еще работающим старикам их пенсии. Однако многие пенсионеры вынуждены работать, несмотря на слабое здоровье, хотя бы на полставки не от хорошей жизни.

Выступая на пленарном заседании Государственной Думы 13 ноября 2019 года, глава Пенсионного фонда России Антон Дроздов заявил, что отказ от индексации пенсий работающим пенсионерам сэкономил для бюджета 368 млрд. рублей на 2020 год. Когда правительством обсуждался вопрос о повышении пенсионного возраста, говорилось, что это необходимо прежде всего для увеличения размеров пенсий, но повышение пенсионного возраста не повлекло даже минимального увеличения реальной пенсии.

Пенсионный фонд прогнозирует увеличение среднего размера страховой пенсии для неработающих пенсионеров с 15,4 тыс. руб. (2019 год) до 16,4 тыс. руб. в 2020 году. Однако пенсия, которая позволит достойно встретить старость, с точки зрения россиян, должна быть не менее 40 тыс. руб., таковы результаты социологического исследования, проведенного сервисом Superjob.

По данным Росстата средняя зарплата в России в апреле 2019 года составляла 47,6 тыс.руб., при этом 71,2\% россиян получают официальную зарплату ниже этого размера. Численность же россиян с денежными доходами ниже прожиточного минимума во втором квартале 2019 года составила 18,6 млн. человек, или $12,7 \%$ от всего населения страны.

Федеральным законом [3] утверждена формула расчета пенсии по старости (1)

$$
\text { СПст }=\text { ИПК } \times \text { СПК }+Ф B,
$$

где СПст - размер страховой пенсии по старости;

ИПК - сумма индивидуальных пенсионных коэффициентов за все годы работы;

СПК - стоимость одного пенсионного коэффициента по состоянию на день, с которого назначается страховая пенсия по старости;

ФВ - фиксированная выплата.

По приведенной формуле подсчитаем пенсию для работников с минимальным размером оплаты труда (МРОТ с 01.01.20 г. - 12130 руб.). В 2020 году величина ИПК такого работника соста- 
вит 1,12 . Предположим, что за каждый год работы ИПК был на этом же уровне, тогда за 37 лет страхового стажа будет заработано пенсионных коэффициентов в общей сумме $41,44(1,12 \times 37)$. Так как стоимость пенсионного коэффициента, установленного на 2020 год, составляет 93 руб., а размер фиксированной выплаты - 5686,25 руб., то размер пенсии составит: $41,44 \times 93+5686,25=$ 9540,17 руб.

Однако такой простой подсчет не приводит к получению точного количества баллов, т.к. размер страховых взносов, рассчитанных с фактической зарплаты нужно разделить на размер страховых взносов с предельной величины базы в соответствующем году и умножить на 10 . Предельная величина базы для начисления страховых взносов в пенсионный фонд ежегодно устанавливается постановлением Правительства Российской Федерации. Например, при доходе 45 тыс. руб. в месяц (за год 540 тыс. руб.) в 2016 году работник получил от пенсионного фонда 6,78 ИПК (пенсионных балла), в 2019 году $-4,7$ балла, а в 2020 году, при новой предельной величине, уже 4,18 балла. То есть с каждым годом зарабатывается все меньше баллов.

Таким образом, долгосрочный пенсионный прогноз для большинства сограждан негативен. Получаемая пенсия все в меньшей степени будет возмещать утраченный в связи с нетрудоспособностью заработок.

Теперь рассмотрим пример расчета пенсии для работников с высокой зарплатой (более 107 тыс. руб. в месяц в 2020 году). Предельная величина базы для начисления страховых взносов в пенсионный фонд на 2020 год составляет 1292 000 руб.- это максимальный годовой размер, в пределах которого с зарплаты отчисляются взносы на страховую пенсию. Если годовая зарплата выше, то пенсия все равно формируется в пределах этой суммы. Максимальное значение ИПК с 2015 года ежегодно увеличивалось, на 2020 год оно составит 9,57, а начиная с 2021 года и все последующие годы - 10 [3, с. 44]. Таким образом, работники с высокой зарплатой за год могут заработать 10 баллов, а за 37 лет работы 370 баллов. Если бы работник набрал такое количество баллов к 2021 году, то размер его пенсии составил бы: $370 \times$ 98,86 + 6044,48 = 42622,68 руб.

Получается, что согласно [3], это максимально возможная пенсия. Откуда тогда берутся пенсии в 400 тыс.руб., в 700 тыс.руб. и выше?
Еще одна проблема - это трудоустройство в связи с увеличением пенсионного возраста. В России при среднем уровне безработицы 4,9\% уровень безработицы среди предпенсионеров остается экстремально высоким.

Из 10,1 млн. граждан «серебряного» возраста официально работают только 4 млн. На 1 января 2019 года в России было 4,3 млн. мужчин 1959-1963 годов рождения. Из них работает только 1,8 млн. человек. Из женщин 1964-1968 годов рождения (5,8 млн.) трудоустроены лишь 2,2 млн. Отмечается, что из 6 млн. безработных предпенсионеров некоторые закончили трудиться раньше срока, а другие не могут работать из-за инвалидности [1].

Ко всему вышесказанному добавлю, что доходы ПФР в последнее время оказались выше запланированных, в связи с чем был даже уменьшен трансфер из федерального бюджета. Российский бюджет также сейчас является сверхпрофицитным из-за высоких нефтяных доходов.

Почему у государства с богатейшими природными ресурсами не хватает денег на выплату достойных пенсий, а доходы от добычи и использования этих самых ресурсов стекают в карманы олигархов? Почему всегда находятся много миллиардные средства для помощи разным странам мира, но не находится средств для помощи нуждающимся гражданам собственной страны?

Работников призывают зарабатывать больше, чтобы больше отчислений производить в Пенсионный фонд. Но это невозможно при сложившемся уровне заработной платы в большинстве регионов России. Большинство проблем в стране связано именно с низким уровнем заработной платы. Сбалансированность пенсионной системы связана еще с одним показателем: количество работающих на одного пенсионера. В настоящее время на одного пенсионера приходится 1,3 работающих, а необходимо добиться показателя -3 работающих на одного пенсионера. Достижение этого показателя связано не только с увеличением пенсионного возраста, но прежде всего с увеличением рождаемости. А это в свою очередь напрямую зависит от уровня заработной платы.

Вывод из всего сказанного. Пенсионная реформа не обеспечила устойчивость пенсионной системы в стране и улучшение качества жизни 
пенсионеров. Для увеличения пенсионного возраста должны быть объективные предпосылки:

- расширение спектра занятости населения, создание новых рабочих мест;

- развитие здравоохранения и поддержание здоровья населения;

- увеличение продолжительности жизни и трудоспособного возраста;

- развитое, стабильное экономическое состояние страны;

- высокий уровень благосостояния граждан.

Нужно развивать экономику, расширять производство, повышать заработную плату, а с ней и страховые взносы и отчисления в пенсионный фонд увеличатся без повышения тарифов. А если Россия, являясь частью мировой эко- номики, будет выполнять в ней роль сырьевого придатка и зависеть от мировых цен на энергоносители, достойный уровень жизни пенсионерам гарантировать невозможно.

Если пенсионный фонд стремится к экономии средств и увеличению размера пенсий для большинства пенсионеров, то нужно прежде всего пересмотреть систему пенсий для силовиков и госчиновников, отказаться от доплат к пенсиям госслужащим, в том числе депутатам Государственной Думы. Меньше тратить на содержание самого Пенсионного фонда. Кроме этого, на законодательном уровне принять решение о пополнении Пенсионного фонда за счет нефте- и газодобычи.

\section{Библиографический список}

1. В России подсчитали количество безработных предпенсионеров. // Свободная пресса - общественнополитическое интернет-издание.[сайт]. URL: https://svpressa.ru/society/news/242112/ (дата обращения 10.12.2019).

2. Конвенция Международной Организации Труда № 102 о минимальных нормах социального обеспечения (Женева, 28 июня 1952 г.) [сайт].URL: https: //www.ilo.org/wcmsp5/groups/public/--ed norm/--normes/ documents/normativeinstrument/wcms_c102_ru.pdf (дата обращения 10.12.2019).

3. Федеральный закон от 28.12.2013 № 400-ФЗ (ред. от 01.10.2019) «О страховых пенсиях».Доступ из справ.-правовой системы «КонсультантПлюс». [сайт]. URL: http://www.consultant.ru (дата обращения 10.12.2019).

4. Федеральный закон от 28.12.2013 № 424-Ф3 (ред. от 03.10.2018) «О накопительной пенсии». Доступ из справ.-правовой системы «КонсультантПлюс». [сайт]. URL: http://www.consultant.ru (дата обращения 10.12.2019).

5. Федеральный закон от 03.10.2018 № 350-Ф3 «О внесении изменений в отдельные законодательные акты Российской Федерации по вопросам назначения и выплаты пенсий». Доступ из справ.-правовой системы «КонсультантПлюс». [сайт]. URL: http://www.consultant.ru (дата обращения 10.12.2019).

6. Федеральный закон от 17.12.2001 № 173-Ф3 «О трудовых пенсиях в Российской Федерации». Доступ из справ.-правовой системы «КонсультантПлюс». [сайт]. URL: http://www.consultant.ru (дата обращения 10.12.2019).

7. Федеральный закон от 15.12.2001 № 166-Ф3 «О государственном пенсионном обеспечении в Российской Федерации». Доступ из справ.-правовой системы «КонсультантПлюс». [сайт]. URL: http://www.consultant.ru (дата обращения 10.12.2019).

8. Федеральный закон от 15.12.2001 № 167-ФЗ «Об обязательном пенсионном страховании в Российской Федерации». Доступ из справ.-правовой системы «КонсультантПлюс». [сайт]. URL: http://www.consultant.ru (дата обращения 10.12.2019). 